signals. However the inherent instability of the SRI hampers elucidation of its molecular mechanism. Recently we found and characterized a new SRI from a eubacterium Salinibacter rubber (SrSRI) [1]. The high stability of SrSRI allowed us to obtain more detailed information about signaling mechanism of SRI.

Fourier transform infrared (FTIR) spectroscopy is a powerful tool to investigate structural changes in photoactive proteins $[2,3]$. In this study, we applied FTIR spectroscopy to explore structural changes of SrSRI. Because of the improved sample stability in the absence of salt, we were able to obtain the difference spectra of $\mathrm{SrSRI}$ upon formation of the $\mathrm{K}$ and $\mathrm{M}$ intermediates with high signal-to-noise ratio, which includes water signals. The spectra of SrSRI are compared with those of other archaeal rhodopsins such as SRI from $H$. salinarum (HsSRI), sensory rhodopsin II (SRII), bacteriorhodopsin (BR) and halorhodopsin (HR) [4]. We like to discuss similarities and dissimilarities of structure and structural changes between SRI and other microbial rhodopsins.

[1] Kitajima-Ihara, Furutani, Suzuki, Kandori, Homma and Sudo (2008) J Biol Chem in press.

[2] Furutani, Shibata and Kandori (2005) Photochem Photobiol Sci 4, 661

[3] Sudo, Furutani, Spudich and Kandori (2007) J Biol Chem 282, 15550.

[4] Suzuki, Sudo, Furutani, Takahashi, Homma and Kandori, to be submitted.

\section{P-270 バクテリオロドプシンのプロトン輸送過程におけるへリックスーB,} Cのキンク構造の動的過程: 固体 NMR による解析

The role of kinked structures in the $\mathrm{B}$ and $\mathrm{C} \alpha$-helices of bacteriorhodopsin in proton transfer, as studied by solid-state NMR

Atsushi Kira (1)(2), Michikazu Tanio(3), Izuru Kawamura(1), Satoru Tuzi(3), Hazime Saito(3)(4) and Akira Naito (1). (l: Graduate School of Engineering., Yokohama National University.; 2: R\&D div., ULVAC Inc.; 3: Dept of Life Science, Himeji Inst. of Tech. (Univ of Hyogo); 4:Hiroshima Univ

Bacteriorhodopsin from the purple membrane of Halobacterium salinarum is a light-driven proton pump, consisting of the seven transmembrane $\alpha$-helices with retinal covalently linked to Lys 216 through protonated Schiff base (SB). After the first proton transfer from the protonated SB to the anionic Asp85, the electric charges at SB and Asp85 disappear. It was proposed that conformation and dynamics changes could be associated with the kinked structures in the B and C helices, leading to proton release and uptake. We aimed to examine here such dynamics changes caused by altered electric charge at Asp85 and $\mathrm{SB}$, using $\left[1-{ }^{13} \mathrm{C}\right]$ Val- or - Pro-labeled D85N single or double mutants by solid-state ${ }^{13} \mathrm{C}$ NMR. We found that ${ }^{13} \mathrm{C}$ NMR signal of Val49 from D85N mutant(s) was suppressed concomitant with deprotonation of SB as a result of interference of fluctuation frequency at Val49 with frequency of magic angle spinning. Nevertheless, the Pro50 signal adjacent to with Val49 turned out to be unchanged irrespective of the charged state of SB. This reveals an increase in fluctuation at $10^{4} \mathrm{~Hz}$ of the B helix at the cytoplasmic side of Pro 50 included in the kink as a result of protonation of the SB. Furthermore, it is found that the kink consisted of Pro91 at the $\mathrm{C}$ helix acquired local fluctuation motion with a frequency in the order of $10^{4} \mathrm{~Hz}$ due to deprotonation of SB. Accordingly we propose here that the dynamics changes at the cytoplasmic side of the $\mathrm{B}$ and $\mathrm{C}$ helices induced by modified charged states of Asp85 and SB contribute to a reduced $\mathrm{p} K_{\mathrm{a}}$ for $\mathrm{Asp} 96$.

\section{P-271 錐体視物質のトランスデューシン活性化効率の解析}

Analysis of transducin activation efficiencies of cone visual pigments Ichirota Seki, Yasushi Imamoto, Takahiro Yamashita and Yoshinori Shichida of Biophysics, Graduate School of Science, Kyoto University

Department

Cones exhibit photoresponses faster but less sensitive than those of rods. These differences could be partly accounted for by the differences in formation and decay rates of active state (meta-II intermediate) and its turnover rate for transducin between rod and cone visual pigments. It has been revealed that formation and decay rates of meta-II intermediate of cone pigment are faster than those of rod pigment (rhodopsin). However, because of the fast decay of meta-I intermediate of cone pigment, its turnover rate for transducin was little analyzed. In the present study, we have tried to estimate transducin activation efficiency of chicken green-sensitive cone visual pigment (cG), by using mutants that exhibited decay time of meta-II intermediate similar to that of rhodopsin. We also prepared rhodopsin mutants having decay time of meta-II intermediate similar to that of cG. The activation of transducin or the decay of meta-II was monitored by the fluorescence increase of tryptophane, which is the indication of the formation of GTP-bound form of transducin or opsin. The results demonstrated that $\mathrm{cG}$ mutants exhibited lower turnover rate of transducin than rhodopsin and inhibition of opsin formation by transducin occurred in rhodopsin but not in $\mathrm{cG}$ mutants. Based on these results, we will discuss the difference in the affinity for transducin and the catalytic activity of GDP/GTP exchange reaction between rod and cone pigments.

\section{P-272 パリエトプシンの光反応}

Photoreaction of parietopsin

Kazumi Sakai (1), Yasushi Imamoto (1), Takahiro Yamashita (1), Hisao Tsukamoto (2) Akihisa Terakita (2), Chih-Ying Su (3), King-Wai Yau (3), and Yoshinori Shichida (1). (1. Department of Biophysics, Graduate School of Science, Kyoto University; 2: Department of Biology and Geosicence, Graduate School of Scinece, Osaka City University; 3: Department of Neuroscience, Johns Hopkins University School of Medicine)

In lizards and some other lower vertebrates, there is a parietal eye at the top of head, which is proposed to mediate the global detection of dawn and dusk.
While the parietal eye photoreceptor cells resemble rods and cones in morphology, they exhibit unique photoresponses. They are depolarized in response to green light under dark-adapted conditions, but exhibit hyperpolarized response when blue light is superimposed with the ambient green light. Parietopsin, which is a green sensitive pigment, was identified from parietal eye photoreceptor cells in 2006 [1]. Immunocytochemistry and whole-cell recordings of the photoreceptor cells suggested that parietopsin couples to Go but not gustducin, a transducin homolog, and produces a depolarizing response, although parietopsin is phylogenetically close to the transducin-coupled vertebrate visual pigments and far from the Go-coupled invertebrate visual pigments. Therefore, it is of evolutionary interest to compare molecular properties and G protein activation mechanism of parietopsin with those of vertebrate and invertebrate pigments. Like invertebrate rhodopsins, parietopsin contains counterion (E171) in its second extracellular loop. On the other hand, it converts to meta-I-, meta-II- and meta-III- like intermediates after absorption of a photon. We will discuss the unique properties of this ancient vertebrate-type opsin, parietopsin.1. Su et al. (2006) Science 311, 1617-1621

\section{P-273 G タンパク質 $\alpha$ サブュニットC 末端部位におけるロドプシン中間 体との結合および活性化制御部位の分離}

Analysis of the regions in the $\mathrm{C}$-terminus of $\mathrm{G}$ protein alpha subunit controlling the binding and activation efficiency by rhodopsin

Naoki Kimata (1), Takahiro Yamashita (1), Takefumi Morizumi (1), Akihisa Terakita (2), Yasushi Imamoto (I) and Yoshinori Shichida (l). (1: Dept. Biophysics, Graduate School of Science, Kyoto Univ.; 2: Dept. Biology and Geosciences, Graduate School of Science, Osaka city Univ.)

Bovine rhodopsin is one of $\mathrm{G}$ protein-coupled receptors and consequently converts into the $\mathrm{G}$ protein-interacting intermediates, metarhodopsin $\mathrm{Ib}$ (metalb) and metarhodopsin II (metaII) when absorbing photons. It can activate Gi group G proteins (Gi, Gt and Go) but hardly Gs and Gq. Our previous study revealed that Go could bind to metalb as efficient as $\mathrm{Gi}$ and $\mathrm{Gt}$ but bind to metall less efficient than those [1]. Thus in the present study, we have investigated the detailed mechanism of interaction between metall and $\mathrm{Gi}$ group $\mathrm{G}$ proteins.

Mutant $\mathrm{Gi}$ whose alpha subunit has the $\mathrm{C}$-terminal 11 amino acids of Goo (Gi/o11) binds to metaII less efficient than wild-type Gi and mutant Gi whose alpha subunit has the C-terminal 5 amino acids of $\mathrm{Go} \alpha(\mathrm{Gi} / \mathrm{o5})$ does less efficient too. On the other hand, biochemical GTP $\gamma \mathrm{S}$ binding assay indicated that activation efficiency of $\mathrm{Gi} / \mathrm{o} 5$ was as large as wild-type $\mathrm{Gi}$ while that of Gi/o11 was smaller than wild-type. These results suggested that the substitution of the C-terminal 5 amino acids changes the binding efficiency to metall and additional substitution of 6 amino acids does the activation efficiency by metall. We will discuss the regions controlling the binding and activation efficiency in the C-terminal sequence of Gia.

[1] Morizumi, Kimata et al. (2008) Photochem. Photobiol. In press.

\section{P-274 Photoactive Yel low Prote in 中の 2 種の Short Hydrogen Bond の} 直接観測

Direct observation of two distinct types of short hydrogen bond in Photoactive Yellow Protein

Shigeo Yamaguchi (1), Hironari Kamikubo (1), Kazuo Kurihara (2), Ryota Kuroki (2), Nobuo Niimura (3). Nobutaka Shimizu (4), Yoichi Yamazaki (1) and Mikio Kataoka $(1,2)$. (1: Graduate School of Materials Science, Nara Institute of Science and Technology; 2: Japan Atomic Energy Agency; 3: Ibaraki University; 4: Japan Synchrotron Radiation Research Institute)

Hydrogen bond dominates various physical properties in biological molecules and biological chemical reactions including proton transfer, hydrolysis, and so on. A special type of hydrogen bonds, the short hydrogen bond (SHB), has been proposed to have an important role in protein structure and function. The physical properties of SHBs, however, are still under debate. In the photoactive yellow protein (PYP), a light sensor protein, two SHBs near the chromophore have been revealed by X-ray crystallographic studies. The bond distances of the SHBs are modulated during the photo-reaction, resulting in the local proton transfer. From these facts, it can be postulated that these SHBs play a crucial role in the local proton transfer. Using high-resolution neutron crystallography in combination with high-resolution X-ray crystallography, we identified two deuterium atoms involved in two SHBs in PYP. One SHB, between the chromophore and E46, is identified as a low-barrier hydrogen bond (LBHB); the other, between the chromophore and Y42, is a short ionic hydrogen bond (SIHB). This is the first direct evidence of the coexistence of two distinct SHBs in the ground state of a protein. At the conference, we will present the neutron crystallographic structure and discuss the two SHBs in PYP.

\section{P-275 部位特異的蛍光標識を用いた G タンパク質活性化効率の異なるロ ドプシン類の活性状態の構造比較解析}

Comparative study on active state structures of rhodopsins having functionally varied properties using site-directed fluorescence labeling

Hisao Tsukamoto (1), David L. Farrens (2) and Akihisa Terakita (1). (1: Dept Biology \& Geosciences, Graduate School of Science, Osaka City University; 2: Dept Biochemistry and Molecular Biology, School of Medicine, Oregon Health \& Science University)

Rhodopsins are members of $G$ protein-coupled receptor (GPCR) family and function in visual and non-visual photoreceptor cells of vertebrates and invertebrates. In general, GPCRs which received signals are converted from inactive state to active state, which activates $G$ protein. Crystal structures of 